\title{
Nest-site selection by the white-tailed eagle and black stork - implications for conservation practice
}

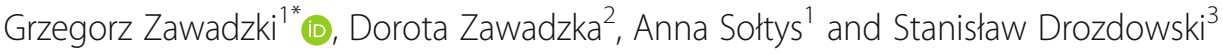

\begin{abstract}
Background: Nesting trees and habitat represent the key factor underpinning stand selection by forest-dwelling birds. While two large European species - the black stork (Ciconia nigra L.) and white-tailed eagle (Haliaaetus albicilla L.) are known to require old, large trees for nesting, we sought to investigate further by comparing species requirements at the levels of the nesting tree, nesting stand, and landscape. This entailed a detailed examination of forest features within circles of radius $15 \mathrm{~m}$ surrounding 16 and 19 trees holding the nests of storks and eagles respectively. The same parameters were also checked in the vicinity of 50 randomly-selected mature trees.

Results: Our results indicate different nesting preferences, with the eagles entirely confining themselves to Scots pine (Pinus sylvestris L.) - a species also chosen by black storks, which nevertheless regularly favour pedunculate oak (Quercus robur L.). Both species select trees of greater girth than the random ones, but white-tailed eagles choose to nest in the vicinity of patches of mature old stands with a loose canopy, to the extent that nesting trees and surrounding trees are of similar ages. In contrast, black storks prefer "veteran" trees with low-set crowns that are much older than any others in their vicinity. Nesting trees of the eagles are away from roads and close to lakes, while black storks do not avoid roads.

Conclusions: As the ages of nesting trees of both species are greater than ages at final cutting in this region's managed forest, silvicultural measures will need to be adjusted, with small patches of forest spared, or larger areas as "islands" of old-growth. Likewise, as tending and thinning are engaged in, certain trees with horizontal branches will need to remain, with relict trees also left untouched. As it happens, all of these recommendations are anyway key elements of close-to nature silviculture and multifunctional forestry.
\end{abstract}

Keywords: Augustów Forest, Poland, Ciconia nigra, Haliaeetus albicilla, Nesting requirements, Protection of nest sites, Old trees, Forest management

\section{Background}

Forest management exerts a strong impact on such important features of forest habitat as age, structure, shares in different phases of development, tree size and treespecies composition, canopy cover, and proportion of undergrowth. Forest practices also transform the texture of forests. Forester-induced habitat changes thus shape

\footnotetext{
* Correspondence: gzawadzki@wl.sggw.pl

1 Department of Forest Protection, Institute of Forest Sciences, Warsaw University of Life Sciences, Nowoursynowska 159, 02-776 Warszawa, Poland Full list of author information is available at the end of the article
}

the conditions for many species of animal inhabiting forest ecosystems; and resource availability important for certain forest-dwelling species may actually be limited by forest practices (Jokimäki and Solonen 2011; Zawadzka et al. 2016; Banaś et al. 2019). Structural parameters whose availability shapes the presence or absence of certain species of forest bird (e.g. dead wood, old-growth trees and cavity trees) are all found to be less available in managed forest than the natural counterpart (Rosenvald et al. 2011; Walankiewicz et al. 2014). Thus both the ranges and abundance of forest birds (and especially forest 
specialists) are reduced by human activity, with birds lacking places to breed and/or food resources in these contexts (Penteriani 2002; Lõhmus 2003; Rosenvald and Lõhmus 2003; Zuberogoitia and Martinez 2011). A number of endangered species are associated with old, mature forests, and stand age as related to diversity of structure is known to be especially important for certain kinds of raptors and owls, as well as for the black stork (Ciconia nigra L.) (Lõhmus 2003; Rosenvald and Lõhmus 2003; Treinys et al. 2009a, b; Mikusiński et al. 2018).

A key element of breeding habitat for birds is the presence of nest sites (Zawadzki and Zawadzka 2017), while the lack of suitable places to nest is associated with lower populations of certain bird species in managed forest. This seems especially true of large birds in need of large trees if they are to nest (Lõhmus and Sellis 2003; Zuberogoitia and Martinez 2011). The declining share and fragmentation of old forest may be conducive to competition for a nesting tree among birds of prey assemblages (Skuja and Budrys 1999; Hakkarainen et al. 2004; Treinys et al. 2011; Skuja et al. 2019). In Poland, since 1984, the law has provided that the nests of the 10 most-endangered bird species are safeguarded yearround within protection zones extending out to a radius of $200 \mathrm{~m}$, and to a radius of $500 \mathrm{~m}$ during the breeding season. Regulations also preclude the felling of old trees needed as nest sites, as well as ensuring the preservation of patches of old, mature forest (Zieliński et al. 2011; Anderwald et al. 2014). However, the protection zones provided for in law do not protect potential breeding sites and trees, only existing, occupied nests.

A raptor species enjoying this kind of zone protection in Poland is the white-tailed eagle (Haliaeetus albicilla L.) - the largest bird of prey living in Europe's forests, reaching body masses of 4 to $5 \mathrm{~kg}$, and wingspans of up to $2.5 \mathrm{~m}$. This bird chooses large trees in which to construct huge nests used long-term and capable of exceeding $1 \mathrm{t}$ in weight (Cramp and Simmons 1980). In Poland, the population of this species has shown strong growth in numbers - associated with a major expansion in range - over the last 40 years (Zawadzka et al. 2009; Chodkiewicz et al. 2019).

A second specially-protected bird species is the black stork. Body mass in this case reaches some $3 \mathrm{~kg}$, while the wingspan may be of as much as $180 \mathrm{~cm}$. The black stork inhabits stands of old forest located near shallow wetlands, given the selection of large, old trees as places to build nests, along with a habit of feeding in shallow streams and other bodies of water, as well as drainage ditches (Cramp and Simmons 1980; Janssen et al. 2004; Zbyryt 2013). While the national population of the species seems more or less stable (Chodkiewicz et al. 2019), numbers in NE Poland have been in long-term decline (Pugacewicz 2015; Zawadzki G, unpubl. data).
The white-tailed eagle and black stork are the largest forest birds nesting on large trees to inhabit European forests; and both enjoy strict protection, while both are also listed in Annex 1 to the EU's "Wild Birds Directive" (Directive 2009/147/EC of the European Parliament and of the Council of 30 November 2009 on the conservation of wild birds). Moreover, both can be regarded as species indicative for forest-dwellers in general, capable of serving as paradigms where sustainable forest management is concerned (Angelstam et al. 2004; Basile et al. 2016). And, while the systematic positions of the two differ markedly, the biology and ecology are similar, not least as regards the long-term use of nests that undergo an element of reconstruction in each new year of use. In that kind of context, the black stork has already been the subject of joint studies with the whitetailed eagle (e.g. Rosenvald and Lõhmus 2003), or appeared in papers alongside other forest raptor species (Stój 1996; Skuja and Budrys 1999; Treinys et al. 2011; Skuja et al. 2019).

The work described in this paper therefore examined nest-site selection in these two large, co-existing species of forest specialist, on the three spatial scales: of the nesting tree, the nesting stand and the landscape. Our hypotheses were: (i) the nesting requirements of the two bird species do differ; and (ii) the nesting sites of both eagles and storks will differ from places in the forest selected at random, implying special needs of both where forest management is concerned.

We first compared habitat requirements in detail, to address the potential for competition between the two species over nesting trees (that might show either similarities and differences), as well as breeding sites on the larger scale. This reflected the key need for further study to preclude direct interactions, and in fact the possibility that different regional trends noted for the two species relate straightforwardly to competition in the face of limited availability of breeding sites - very large, old trees. It also reflected a desire to improve methods of habitat management pursued in the interests of the two rare species. It was anticipated that, as result of the work, we would be in a position to formulate recommendations aiming at the better protection, and also the active development, of places for the studied bird species to nest, by way of forest practices pursued in stands of hemi-boreal and mixed/pine forest.

\section{Material and methods \\ The study area}

The relevant work was carried out in the complex known as the Augustów Forest (AF), whose Polish part is in the NE of the country (at $23^{\circ} 15^{\prime}$ E, $53^{\circ} 54^{\prime}$ N, Fig. 1), and extends over some $1140 \mathrm{~km}^{2}$. This is a fairly flat area, with a range of elevations between 135 and $190 \mathrm{~m}$ 


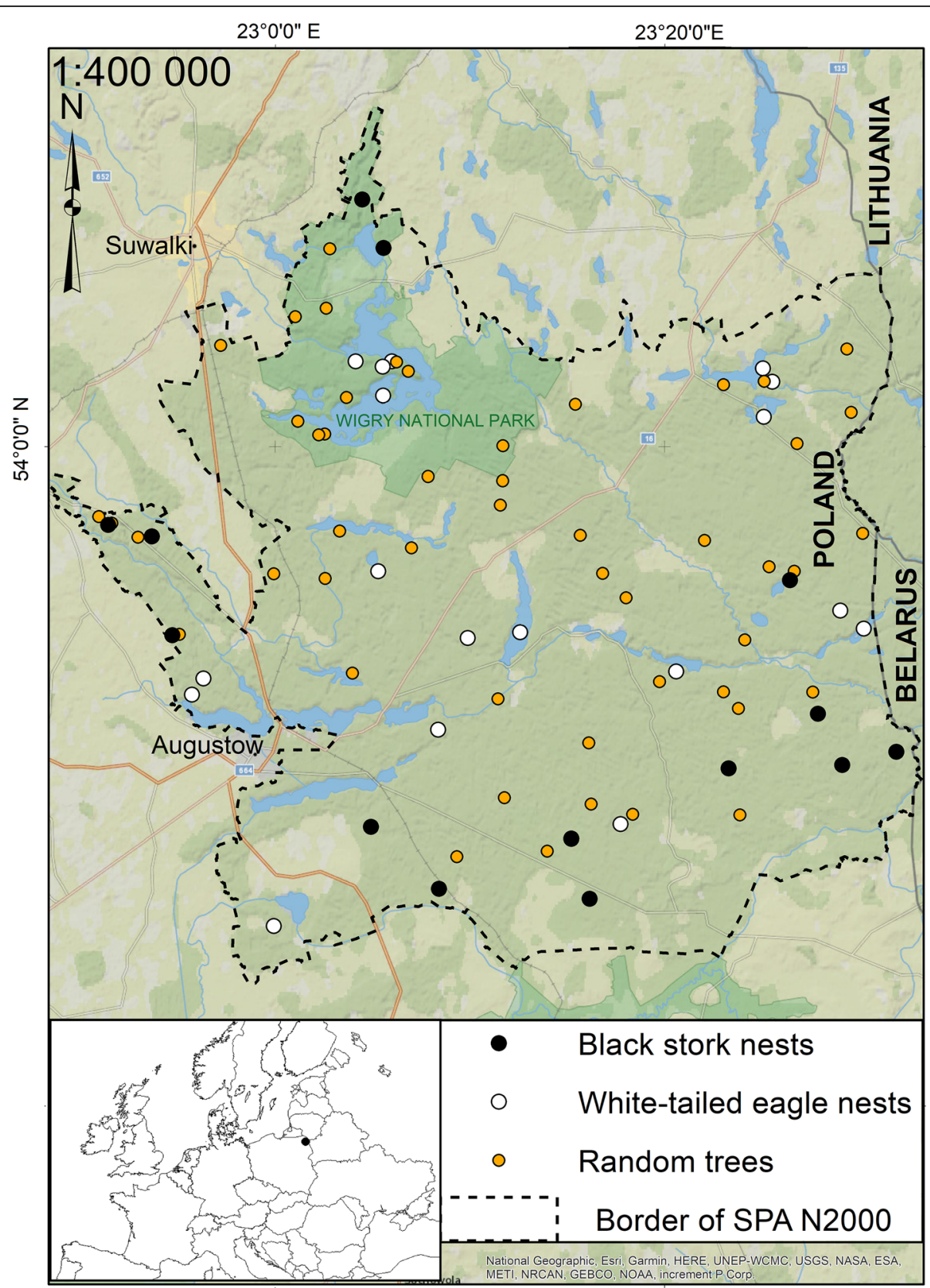

Fig. 1 Study area. Distribution of the study plots within the Augustów Forest

a.s.l. The climate is relatively cold, with a mean annual temperature of $6.5^{\circ} \mathrm{C}$, a 135-day growing season, and snow cover typically present for around 100 days a year. Forest cover here is of around 93\%, while lakes account for a further $6 \%$ of the area. The mean age of tree stands is 65 years, but stands over 100 years old account for about $15 \%$ of the overall area of forest. These stands are dominated by Scots pine (Pinus sylvestris L.) (78\%), Norway spruce (Picea abies (L.) H. Karst) (8\%), black alder (Alnus glutinosa Gaertn.) (9\%), silver birch (Betula verrucosa Roth) (5\%), and pedunculate oak (Quercus robur L.) (1\%). Among the forest site types, mesic pine forest accounts for almost $40 \%$ of the area, while $27 \%$ is in the form mesic mixed/coniferous forest. Some $7 \%$ of the forest area is of pine bog forest. Wet forest sites are located mainly in the southern part of AF, whereas mesic pine forest occurs around the lakes of the northern part. Protected areas (a national park and 14 nature reserves) extend over $16.8 \%$ of the whole forest complex. Lake Wigry National Park - of $150.8 \mathrm{~km}^{2}$ - is located in the NW part of AF, which is a site included in Europe's Natura 2000 network - as Special Protection Area for 
Birds PLB200002 "Puszcza Augustowska". Nevertheless, most of the area comprises commercial stands managed within and by six forest districts of Poland's State Forests National Forest Holding.

\section{Data collection}

Searches and checks were carried out across Augustów Forest. Trees used by eagles for nesting were inventoried in the course of research into the species (Zawadzka et al. 2006, 2017). Nesting trees for black storks (hereinafter "stork trees") were sought during work to inventory and monitor birds protected within protection zones around their nests (Zawadzka D and Zawadzki G, unpubl. data).

Data were collected in 2015-2019, including measurements outside the breeding season. We analysed 19 active "eagle trees" falling within 14 home ranges, and 16 "stork trees" each in different home ranges, with these representing AF's entire population of the eagle, as well as around $70 \%$ of its black storks. Mean distances between nests were of 8.15 and $5.14 \mathrm{~km}$ respectively. We continued to carry out breeding-season checks on whether known nests of storks and eagles came to be occupied by other species of raptor in subsequent years. In a next step, we then analysed 50 trees selected at random, growing a mean distance of $2.83 \mathrm{~km}$ apart.

All known nests were mapped with GPS coordinates on a forest numerical map. We noted DBH and heights of nesting trees, heights of nests above the ground, and heights of the lowest branch of tree crowns above the ground (Table 1). We also described the manner of the placement of a nest in a given tree, by reference to the categories: (i) on top of the crown, (ii) within the crown in the fork between boughs and the trunk, (iii) on a side branch directly at the trunk, (iv) on a side branch at some distance from the trunk.

The next step entailed analysis of habitat features by means of measurement, in relation to circular plots centred on nest trees and with radii of $15 \mathrm{~m}$ (denoting an area of $0.07 \mathrm{ha}$ ) (Table 1). In the case of each tree growing within such a circle, we recorded DBH $>12 \mathrm{~cm}$, as well as species, height, diameter (DBH) and distance from nesting trees, canopy closure of the stand layer, and cover of shrubs and undergrowth (Table 2). Characterisations of stands in such circular study plots located around nests were compared with those based on the same variables (obviously minus parameters connected with nests) describing 50 circular study plots of $15 \mathrm{~m}$ radius surrounding the aforementioned trees selected at random (Table 2).

The aforesaid random points were selected using the ArcMap 10.2.2 program, with data relating to stands in Augustów Forest downloaded from the BDL Forest Data Bank (BDL 2020, https://www.bdl.lasy.gov.pl/portal/ mapy-en). However, as all known "eagle trees" and "stork trees" are more than 100 years old, we decided to restrict comparisons with known nesting trees to trees and places in forest of the same age class and in the same development phase. We sought results that allowed nest trees to be compared with existing potential nesting sites, and therefore avoided locating randomlyselected points among young trees, in forest plantations or felling areas, where the availability of trees suitable for the construction of large nests is very limited. A preference as regards forest age in the species has gained confirmation in other studies (Lõhmus 2003; Rosenvald and Lõhmus 2003; Treinys et al. 2009a, b; Zieliński et al. 2011; Anderwald 2014).

In line with the above principle, we used ArcMap to develop a layer relating solely to forest stands $>100$ years old, anticipating that such stands would include trees of ages potentially attractive to eagles and storks. A total of 50 random points were identified in this layer, prior to identification of these points using coordinates, in order to permit the collection of data in the field. All field works were carried out during the breeding season.

All height measurements were made using the Measureheight application (Bijak and Sarzyński 2015), while

Table 1 Variables used in describing habitat in Augustów Forest featuring nesting trees for white-tailed eagles and black storks

\begin{tabular}{lll}
\hline Parameter & Place of measurement & Value (rank/unit) \\
\hline DBH of tree & $\begin{array}{l}\text { Nesting trees \& random trees } \\
\text { at centers of study plots }\end{array}$ & $\mathrm{cm}$ \\
Tree height & & $\mathrm{m}$ \\
$\begin{array}{l}\text { Branch height (lowest point of tree crown above ground) } \\
\text { Tree species (nesting/random) }\end{array}$ & $\mathrm{m}$ \\
$\begin{array}{l}\text { Tree age (nesting/ random) } \\
\text { Crown height }\end{array}$ & year \\
Height of nest (above ground) & Nesting trees & $\mathrm{m}$ \\
Distance to tree top (from nest) & & $\mathrm{m}$ \\
Placement (of nest on tree) & & top (1), inside crown (2), side branch by trunk (3), \\
\end{tabular}


Table 2 Variables used in describing habitat in Augustów Forest featuring nesting stands for white-tailed eagles and black storks

\begin{tabular}{lll}
\hline Parameter & Place of measurement & Value (rank/unit) \\
\hline $\begin{array}{l}\text { Stand age } \\
\text { Stand species (Main) }\end{array}$ & $\begin{array}{l}\text { Nesting-tree stands \& randomly-selected } \\
\text { stands }\end{array}$ & year \\
Site type & & $\begin{array}{l}\text { oligotrophic (1); mesotrophic (2); } \\
\text { eutrophic (3) }\end{array}$ \\
Humidity & mesic (1); wet (2); bog (3) \\
Cover of canopy & Nesting-tree circular study plots \& random & successive 10\% steps \\
Cover of shrub and undergrowth layers & study plots & successive 10\% steps \\
Distance to neighbors (average from nesting/randomly-selected tree) & & $\mathrm{m}$ \\
No. of neighbours (Number of trees in a 15-m radius) & & $\mathrm{n}$ \\
Neighbour DBH (average DBH of neighbour trees) & & $\mathrm{cm}$ \\
Neighbour height (average height of neighbour trees) & & $\mathrm{m}$ \\
\hline
\end{tabular}

DBH was measured using calipers. Additionally, we used ArcMap to create map of the study area, assess distances of nests from roads, the forest edge, rivers and lakes, using the numerical maps. From the Forest Data Bank we obtained data concerning ages of nesting and random trees, as well as stand species, ages, and forest site types (Table 3).

\section{Statistical analysis}

Our statistical analysis was carried out for the aforementioned three groups ("eagle trees", "stork trees" or randomly-selected trees), so as to identify differences among parameters of nesting trees for the two studied species, and to indicate preferences in relation to selected trees, stands and forest sites in the study area. Descriptive statistics were first obtained, before distributions were tested using statistical applications with $R$ (version 3.3.3) statistical software ( $\mathrm{R}$ Core Team 2019). Statistical analyses began with transformation into the form of factor variables of such category variables as stand species (Pinus sylvestris, Picea abies, Alnus glutinosa, Betula pendula), tree species (Pinus sylvestris, Picea abies, Alnus glutinosa, Quercus robur, Fraxinus excelsior), site type (oligotrophic forest - coniferous forests; mesotrophic forest - mixed forests; eutrophic forest - broadleaved and alder forests) humidity (mesic, wet or boggy) and category of placement of the nest on the tree (top of the crown, within the crown on a fork between branches and the trunk, on a side branch directly by the trunk, or on a side branch at a distance from the trunk). As in all cases, at least one of the three groups ("eagle trees", "stork trees" or "random trees") had a non-normal distribution, we used non-parametric methods. Thus (multiple) comparisons of all groups were made using the Kruskal-Wallis (KW) test, as well as the post-hoc Dunn test if factors were found to differ significantly from one another. For parameters collected for the two groups (connected with nests) we used the Wilcoxon (W) test. To compare ordinal variables (tree species) we used a chi-square test for independence. Unsigned values are given in the order black stork white-tailed eagle - randomly-selected. All statistical calculations were made in relation to an accepted significance level $\alpha=0.05$. We also checked for parametric correlations between pairs of analysed parameters (Table S4). We removed from analyses strongly correlated parameters, whose correlation coefficient " $r$ " was higher than 0.7. Sample size of the nest trees was insufficient for multivariate analysis, hence we used univariate ones.

\section{Results \\ Nesting trees}

During the study, both the stork and the eagle only occupied nests built by their own species. Eagles are found to nest exclusively on specimens of Scots pine - the species also found to be (94\%) dominant among trees selected at random (with spruce, alder and ash on just $2 \%$

Table 3 Variables used in describing habitat in Augustów Forest featuring nesting trees for white-tailed eagles and black storks at the landscape scale

\begin{tabular}{lll}
\hline Parameter & Place of measurement & Value (rank/unit) \\
\hline Distance to road (from nesting tree) & Nesting trees at centres of study plots \& random trees at centres of study plots & $\mathrm{m}$ \\
Distance to forest edge (from nesting tree) & & $\mathrm{m}$ \\
Distance to lake (from nesting tree) & & $\mathrm{m}$ \\
Distance to river (from nesting tree) & & $\mathrm{m}$ \\
\hline
\end{tabular}


each). This was in line with the distribution of pines in Augustów Forest. In contrast, apart from pines (56\%), black storks also nest in oaks (38\%) and alders (6\%). Inter-species differences are therefore noted in species of nesting tree $\left(\chi^{2}=86.02, p<0.001\right)$. Oaks were only noted as neighbouring trees in the cases of 2 eagle trees, 3 stork trees and 5 random trees.

Analysed trees also differ in terms of age $(\mathrm{KW}=8.16$, $p=0.017)$. "Eagle trees" and "stork trees" were older than "random trees", being of age 157 years on average (range 103-200 years) (Fig. 2a, Table S5). In contrast, there are no significant differences between "stork trees" and "eagle trees". While such "stork trees" (of average age 167 years) are older than surrounding stands $(W=153$, $p=0.012$ ), no such difference is found for "eagle trees" $(\mathrm{W}=204.5, p=0.491)$ or randomly-selected ones ( $\mathrm{W}=$ 1266.5, $p=0.641$ ) (Table S5). DBH values in the groups compared are different, with "random trees" (mean $=55$ $\mathrm{cm} \pm 10.7 \mathrm{SD}$, Table S5, Fig. $2 \mathrm{~b}$ ) being thinner than those selected for nesting by either of the two species $(\mathrm{KW}=7.13, p=0.028)$.

Nesting trees studied also differ in height (KW = 11.82, $p=0.003)$. "Stork trees" are of average height $28.1 \mathrm{~m}$, while those selected by eagles are of average height $31.2 \mathrm{~m}$, and randomly-selected trees of $30.8 \mathrm{~m}$ (Fig. 2c, Table S5). The latter two groups do not differ significantly. Eagles and storks build their nests at different heights ( $\mathrm{W}=4.5, p<0.001$ ), the former definitely in more-elevated positions than the latter (Table S5). The nesting trees of the two species differ in heights of the bases of crowns $(\mathrm{KW}=22.78, p<0.001)$, with "stork trees" having crowns set significantly lower than "eagle trees", or ones selected at random (Fig. 2d). The way in which nests are placed by birds also varies $(\mathrm{W}=253$, $p<0.001$ ). It is most typical (in $63 \%$ of cases) for eagles to nest at the top of the crown. This is followed by locations close to the trunk (26\%), or lower in the fork of the crown (11\%). In turn, black storks build their nests
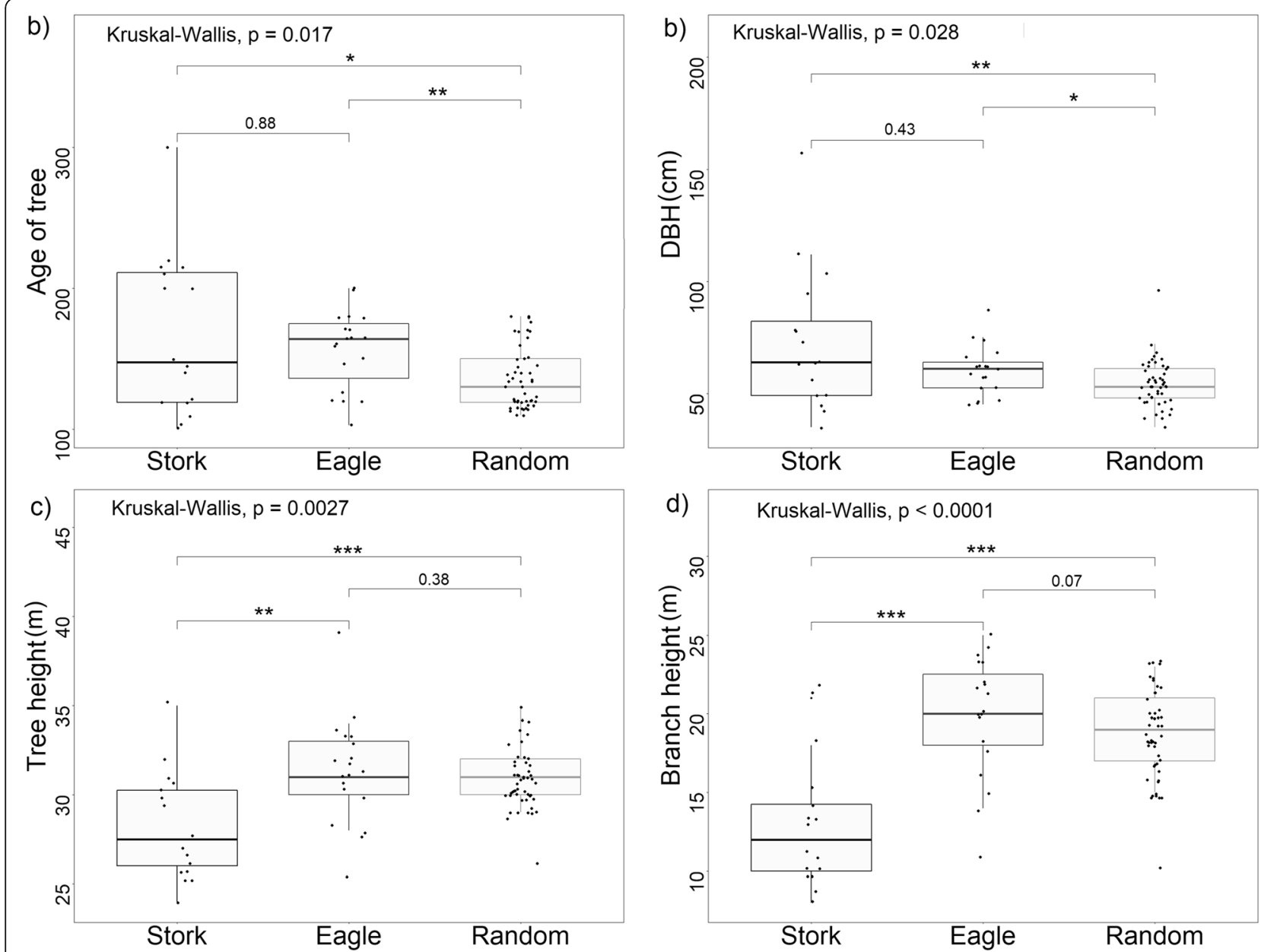

Fig. 2 Comparison of the studied parameters among trees used for nesting by black storks and white-tailed eagles, as well as randomly-selected trees. Abbreviations: $\mathbf{a}$ - age of tree, $\mathbf{b}-\mathrm{DBH}, \mathbf{c}$ - height of tree, $\mathbf{d}$ - height of branch ( ${ }^{*} p<0.05$; ${ }^{*} p<0.01$; ** $\left.p<0.001\right)$ 
on side branches (in $50 \%$ of cases), close to the trunk $(38 \%)$, or in the fork of the crown (12\%).

\section{Nesting stands}

Nests of the bird species studied are located in varied stands. A major difference concerns dominant tree species $\left(x^{2}=80.22, p<0.001\right)$. While the stands used for nesting by eagles are $90 \%$ dominated by pine, with $10 \%$ of spruce; those surrounding the nests of black storks are more diverse, with pine accounting for $56 \%$ of cover, alder $19 \%$, birch $13 \%$ and spruce $13 \%$. In turn, in plots selected for study at random, stands with dominant pine constituted $82 \%$ of the total on average, with spruce on $14 \%$, and birch and alder on $2 \%$ each. Nesting stands and stands selected at random also differ significantly in terms of age $(\mathrm{KW}=15.03, p<0.001)$. Black storks occupy stands that are younger than both those chosen by eagles and those selected at random (Table S5). The difference between "eagle stands" and "random stands" also approaches statistical significance (Fig. 3a). The forest site types used by the two bird species do not differ significantly from each other (Fig. 3b), with oligotrophic forests on $32 \%$ vs $37.5 \%$; mesotrophic forests $68 \%$ vs $12.5 \%$; and eutrophic forests $0 \%$ vs $50 \%$. However, forest stands present on randomly-selected study plots are different ( $K W=9.54, p=0.008)$, being less fertile and humid (respectively: 68\%; 24\%; 8\%). The studied stands also differ in terms of their humidity $(\mathrm{KW}=20.96, p<$ 0.001 , Fig. 3c), with black storks locating their nests in mesic forest (37.5\%), moist forest (25\%) and bog forest (37.5\%), as opposed to eagles selecting stands in mesic forest (84\%) and bog forest (16\%). In this respect, the latter resemble the study plots selected at random (where mesic and bog forest take respective shares of $92 \%$ and $8 \%$ ). The stands within the circular plots around nests also differ in terms of canopy closure $(\mathrm{KW}=16.33, p<0.001)$, with eagles differing from storks in choosing patches with looser closure (Fig. 3d, Table S5). There were no differences in the cover of undergrowth among any of the groups of stands analysed $(\mathrm{KW}=3.94, p=0.139)$.

The circular study plots of radius $15 \mathrm{~m}$ differ significantly in terms of numbers of growing trees $(\mathrm{KW}=21.5$, $p<0.001$, Fig. 3e). "Eagle trees" had distinctly fewer neighbouring trees than did either "stork trees" or those selected at random (Table S5). The heights of trees around the nesting trees also differed $(\mathrm{KW}=15.09, p<$ 0.001). Thus trees around "stork trees" are less tall than the ones surrounding "eagle trees", as well as randomlyselected trees (Fig. 3f, Table S5). However, surrounding trees are of significantly lesser height than the nesting trees and neighbouring trees, which are lower in the cases of black storks ( $\mathrm{W}=123, p=0.003)$, white-tailed eagles $(\mathrm{W}=171, p<0.001)$, and "random trees" $(\mathrm{W}=$
1215, $p<0.001)$. No differences were found for distances separating surrounding trees and either nesting trees or random trees $(\mathrm{KW}=2.75, p=0.249$, Table S5).

\section{The landscape scale}

We examined distances separating nesting trees from other elements of the forest landscape, as well as linear elements. A parameter that does differentiate "eagle trees" significantly from "stork trees" or "random trees" is distance to the edge of a lake ( $\mathrm{KW}=14.24, p<0.001)$, as eagles' nests are located significantly closer to bodies of water than random trees (Fig. 4a, Table S5). Differences between nests of black storks and "random trees" were also on the verge of achieving statistical significance from this point of view. Achieving significance are differences noted for the distances separating both nesting trees and "random trees" from roads $(\mathrm{KW}=17.13$, $p<0.001$ ). The nests of eagles were located significantly further from roads than were either "stork trees" or "random trees" (Table S5). However, "stork trees" are significantly further from roads than "random trees" (Fig. 4b). Similarly, distances separating nesting trees from rivers and streams do not differ significantly $(\mathrm{KW}=$ 2.28, $p=0.319)$. Stork trees were closer to the river (mean $733 \mathrm{~m})$ than eagle trees (mean $997 \mathrm{~m}$ ) and random trees (mean $1170 \mathrm{~m}$ ) (Fig. 4c). While maximum distance to the river was $1700 \mathrm{~m}$ in the case of black storks, for eagles and random places it was over $3000 \mathrm{~m}$ (Table S5). There were no differences between nesting places and "random trees" in terms of distances from the forest edge ( $K W=1.07, p=0.585)$ (Fig. $4 \mathrm{~d}$ ). A total of 5 nests of eagles (26\%) and 3 of black storks (18\%) were located within protected parts of Augustów Forest.

\section{Discussion}

White-tailed eagles and black storks both need old, mature forest for nesting. While the two species might compete on the basis of partially-overlapping habitat requirements, marked differences in habitat selection are to be noted between them (Treinys et al. 2011). As a result of our study, differences present can be viewed in detail, on the three studied scales of the nesting tree, the nesting stand and the landscape. The birds differ clearly in terms of their preferences regarding species of tree to nest in, and place in which to locate the nest. Moreover, there were no incidents of "exchanges" of nests between the studied species, or with other bird of prey species.

\section{Habitat requirements of the black stork}

The black stork prefers some kind of ecologically "residual" tree, a "veteran" still present in the stand, much older than surrounding trees - and able to expand to develop a low, broad crown given a youth spent in the absence of severe competition with other trees. Across 


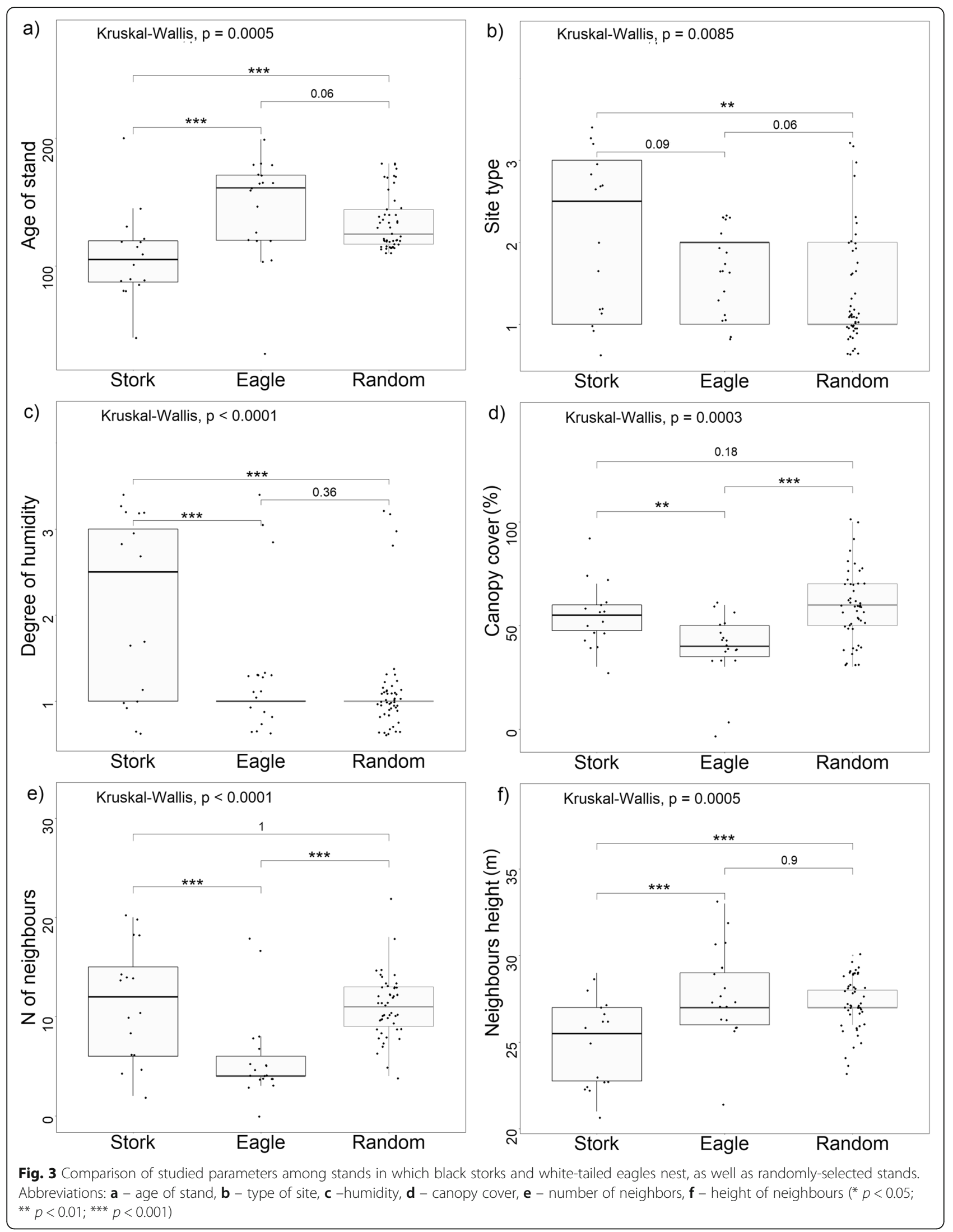




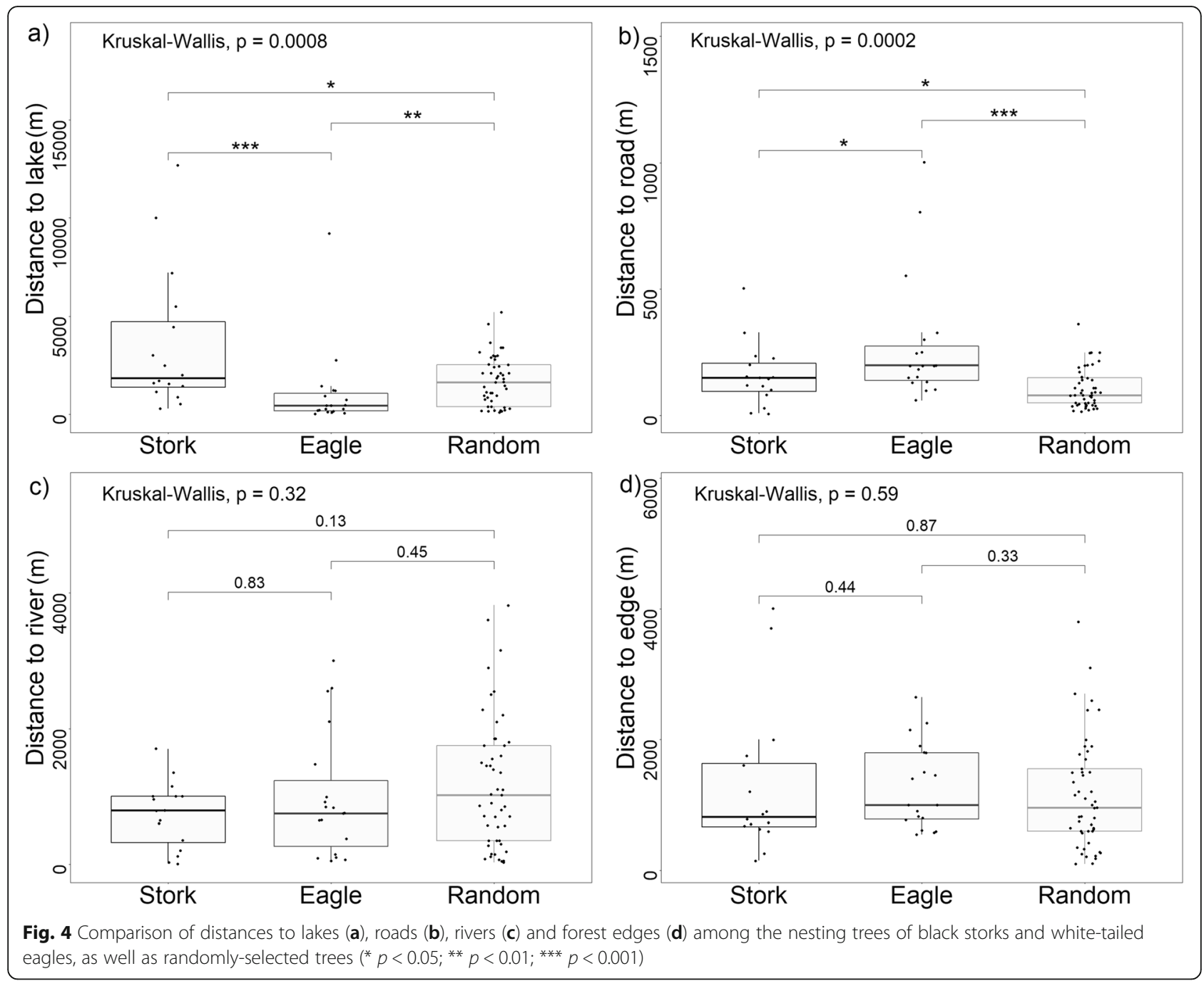

their range, black storks are inclined to construct their nests on trees of above-average size (Lõhmus and Sellis 2003; Vlachos et al. 2008; Zieliński et al. 2011; Poirazidis and Bontzorlos 2017). In central Poland, the birds choose specimen oaks with a DBH of more than $90 \mathrm{~cm}$. A total of $63 \%$ of nests there were found on huge oaks, with $23 \%$ in pines. Interestingly, nests on the latter were constructed on relatively slender trees (of DBH 32-26 $\mathrm{cm}$ ), with distorted crowns (Zieliński et al. 2011). In Estonia, as black storks nest on huge, old trees of average diameter $66 \mathrm{~cm}$, and average age 120 years, availability of potential nest sites is a factor limiting the population (Lõhmus and Sellis 2003). The average age of nesting trees in our study is still higher (at 154 years), but average girths of trees are similar.

The black storks in Augustów Forest build over 60\% of their nests on pine trees, but almost $40 \%$ are in oaks. Against that background, it needs to be highlighted that oaks constitute only just over $1 \%$ of the trees in Augustów Forest. The preference for oak is in fact clear, though not always reflected in a greater number of nests being built in this species (Drobelis 1993; Skuja and Budrys 1999; Lõhmus and Sellis 2003; Olszewski et al. 2017). The high level of resort to pines probably reflects the absolute dominance of this conifer species in the stands present in many regions (with the share of oak being very low in parallel). In turn, it is on oaks that $82 \%$ of black stork nests are founded in Białowieża Forest - a natural site in which old deciduous stands prevail (Pugacewicz 2015). The preference for oak is related to the specific structure of the crown in this tree species. Overall, the black stork may be said to nest in pines opportunistically, when there are too few oaks (Zawadzka et al. 1990; Lõhmus and Sellis 2003).

The humidity and fertility of forest sites are important factors determining the locations of black storks' nest in Augustów Forest. Deciduous forest growing on wet forest sites is preferred, and oak as the preferred species of tree finds optimal conditions for growth there. This can explain why storks' nests are not located on the banks of 
forest streams and rivers, though the latter were closer than they were to the nests of eagles. It could be connected with the abundance of bog and bog forests with standing water. Selectivity in the direction of wet and boggy habitats has also been confirmed for black storks in Lithuania (Drobelis 1993; Skuja and Budrys 1999), Białowieża Forest (Pugacewicz 2015), and Central Poland (Olszewski et al. 2017). The selection of hydrated habitats relates to possibilities for foraging, as well as better safeguarding against martens (Martes sp.) - as key predators among broods of the black stork (Zawadzka et al. 1990).

Stands in Augustów Forest selected for nesting by black storks do not differ in terms of distances from habitat of other types. Lithuania's black storks show a preference for nesting trees set amid continuous forest cover, with fields and the forest edge avoided strongly (Skuja and Budrys 1999). However, as in our work, no avoidance of roads was to be noted (Treinys et al. 2009a, b). Nevertheless, the black storks of central Poland are found to nest in small forest complexes, and hence close to the forest edge (Zieliński et al. 2017).

\section{Habitat requirements of the white-tailed eagle}

Compared with the black stork, the white-tailed eagle is a species less specialised in its requirements regarding nesting trees. Eagles select the tallest, old, pre-eminent, large trees. These have a high-set crown in which the branches are bifurcated in the upper part. Data from the whole Polish population confirm eagles' preferences for the tallest trees, and for trees of greater girth (Anderwald 2014). At 164 years old on average, our study's "eagle trees" are older than the average noted for Poland, i.e. 112 years, including 125 for pine and 93 for alder (Anderwald 2014). Ages of nesting trees are related to the dominant species present in the nesting stand. Scots pines are the trees most selected for nesting by eagles. However, no fewer than 15 species of tree play host to nests in Poland, albeit with $70.3 \%$ in pines, followed by beeches (8.5\%), alders (7.1\%), and oaks (6.4\%) (Zawadzka et al. 2009). In Augustów Forest, the nesting preferences displayed by white-tailed eagles at the level of the stand resemble those in Poland as a whole (Anderwald 2014). Places in which white-tailed eagles nest are seen to stand out on a wider spatial scale, as this raptor chooses mixed/coniferous or broadleaved forest sites in which pine trees also experience optimal conditions for growth. While our study documents eagles' apparent avoidance of deciduous trees and stands, data for the country as a whole reveal that mesic broadleaved forest and mesic pine forest together account for 55\% of nesting stands (Anderwald 2014). However, preferences confirmed here for short distances separating nests from lakes or ponds have often also been documented in the past (e.g.
Lontkowski and Stawarczyk 2003; Zawadzka et al. 2006; Przybyliński 2017).

Recommendations for forest management and protection The presence of potential nesting trees for the two bird species studied differentiates forests in terms of both age and spatial structure, with it unfortunately being clear that habitat requirements fail to coincide with managed forests' commercial functions. Indeed, it is common for the nesting trees of black storks to belong to admixture species, like oak, while storks will also typically choose a single old oak or pine growing in a younger stand of differing species composition. Such trees will only be present at all in managed forest if there is appropriate treatment (i.e. protection) of admixed species during all stages of forest development. In some sense a contrast, but also a challenge for forestry, is the way in which white-tailed eagles are found to need patches of very old forest if they are to nest.

Under these circumstances, both bird species may suffer from a lack of suitable nesting trees in the study area, given established ages of final felling in Augustów Forest equal to 120 years in the case of Scots pine and 140 for oak, i.e. both younger than the nesting trees actually occupied by the area's storks and eagles currently. An impact of typical forest management inimical to the presence of nesting trees or stands was also pointed to by Drobelis (1993), Lõhmus and Sellis (2003), Lõhmus et al. (2005) and Anderwald (2014).

While it is true that all known nests of these species in Poland are surrounded by protection zones, the fact remains that commercial stands at present (and potentially) offer the birds too few suitable trees in which to nest. Zieliński (2006) therefore noted how Poland's nature reserves represent important resources of old oaks that may serve as nesting trees for the black stork. In our study, the fact that 8 nests of the birds studied (23\%) are located within protected areas again emphasises the importance of such areas where conservation of these forest birds is concerned.

Modern multifunctional forestry should thus concede the necessity of patches of forest older than the age at final cutting being left, in order to ensure the preservation of potential nesting trees and stands for white-tailed eagles and black storks (as well as, presumably, other specialised species of forest bird). The exclusion of small fragments of old forest as valuable from the ecological point of view is also recommended in the context of (FSC or PEFC) certification systems. In Polish forestry, it is actually obligatory for islands of old-growth covering at least 10 acres to be left (as 5\% of the area in a clearcutting system) (Silvicultural Guide 2012). Such a policy should also be mandatory in the context of other cutting systems. 
Thus actions to improve habitat conditions for black storks primarily entail the leaving of potential relict trees (especially oaks as biocoenotic trees) as the processes of regeneration, forest tending and thinning are being gone through. Forest tending and thinning should also involve some less-valuable trees with horizontal branches ("wolf trees") being left to grow on and serve as potential nesting trees. This is particularly important in Augustów Forest, because stands here have only a limited share of oak, in line with aspects of geographical range, and both edaphic and climatic conditions.

The leaving of individuals or groups of several (biocoenotic) trees, as well as entire patches of stand (as oldgrowth islands) in a managed forest will have a positive effect in shaping landscape and creating forest structural elements. Indeed, activities of this kind are already promoted within the framework of multifunctional forestry and close-to-nature silviculture (Pommerening and Murphy 2004; Brzeziecki et al. 2013). The suggested solutions should also be implemented in line with the rules for the protection of the studied birds in the context of the "Puszcza Augustowska" Natura 2000 area, as well as other forests within the natural ranges of occurrence of the white-tailed eagle and black stork.

\section{Conclusions}

Nesting preferences of the white-tailed eagle and black stork are found to differ at the detailed level, with eagles needing patches of old and sparse mesic coniferous forest in which there are tall pines over 150 years old, located close to lakes and away from utilised roads. Black storks require individual trees with low-lying horizontal branches that are older than the trees in the immediate vicinity. The black stork prefers wet forest sites, and oaks as trees in which to nest.

Availability of nesting trees thus represents a key factor in the selection of stands by both black storks and white-tailed eagles, in Augustów Forest, where the rotation ages are too low. Efforts to ensure such availability of suitable nesting trees and stands for these birds should thus rely on the retention of small patches of forest (also single trees) older than this area's age at final felling; or even of larger areas - as old-growth "islands" of sparse pine forest. Likewise important in the course of silvicultural measures (like respacing, tending and thinning) is the retention of some trees with horizontal branches, and of relict or residual remnant trees.

All these activities/recommendations in fact represent aspects of the guidelines devised for close-to-nature silviculture, in which the leaving of single trees or old-growth islands through to natural death and decomposition is seen as a very important measure shaping multifunctional forest from the structural point of view. At the same time, independently of forestry measures, an important role assuring resources of nesting trees is obviously also going to be played by protection areas in forests.

\section{Supplementary information}

Supplementary information accompanies this paper at https://doi.org/10. 1186/s40663-020-00271-y.

Additional file 1: Table S4 Correlation matrix for continuous variables analysed (* ${ }^{*}$ highly correlated variables, removed from analyzes). Table S5 Measurement results for parameters describing nesting trees for white-tailed eagles $(H A L)$ and black storks $(C I N)$ versus random trees $(R A N)$

\section{Abbreviations}

EU: European Union; AF: Augustów Forest; NE: North East; NW: North West: DBH: Diameter Breast Height; BDL: Forest Data Bank; KW: Kruskal-Wallis; W: Wilcoxon; FSC: Forest Stewardship Council; PEFC: Programme for the Endorsement of Forest Certification

\section{Acknowledgments}

The authors would like to thank James Richards, Ph.D., for proofreading the manuscript, as well as the anonymous reviewers, for their thoughtful comments and suggestions on the manuscript.

\section{Authors' contributions}

GZ - conception, design of the work, data collection, statistical analysis, data interpretation, draft of the work; DZ - conception, data collection, data interpretation, draft of the work, significant revision, review of the literature; AS - design of the work, data collection and analysis; SD - statistical analysis, review of the literature, significant revision. The authors' read and approved the final manuscript.

\section{Funding}

Own resources, collected without financial support.

\section{Availability of data and materials}

The datasets used and/or analysed during the current study are available from the corresponding author on reasonable request.

Ethics approval and consent to participate

Not applicable.

Consent for publication

Not applicable.

\section{Competing interests}

The authors declare that they have no competing interests.

\section{Author details}

${ }^{1}$ Department of Forest Protection, Institute of Forest Sciences, Warsaw University of Life Sciences, Nowoursynowska 159, 02-776 Warszawa, Poland. ${ }^{2}$ Department of Forestry, University of Łódź, Branch in Tomaszów

Mazowiecki, Konstytucji 3 Maja 65/67, 97-200 Tomaszów Mazowiecki, Poland. ${ }^{3}$ Department of Silviculture, Institute of Forest Sciences, Warsaw University of Life Sciences, Nowoursynowska 159, 02-776 Warszawa, Poland.

Received: 17 April 2020 Accepted: 11 October 2020

Published online: 02 November 2020

\footnotetext{
References

Anderwald D (2014) Drzewa gniazdowe bielika Haliaaetus albicilla przykładem drzew biocenotycznych. Studia i Materiały CEPL 16(4):131-150

Anderwald D, Przybyliński T, Zawadzka D (2014) Podręcznik najlepszych praktyk ochrony ptaków szponiastych. Centrum Koordynacji Projektów Środowiskowych, Warszawa

Angelstam P, Roberge JM, Lõhmus A, Bergmanis M, Brazaitis G, Dönz-Breuss M, Edenius L, Kosiński Z, Kurlavičius P, Lārmanis V, Lūkins M, Mikusiński G, Račinskis E, Strazd M, Tryjanowski P (2004) Habitat modelling as a tool for
} 
landscape-scale conservation - a review of parameters for focal forest birds. Ecol Bull 51:427-453

Banaś J, Zięba S, Bujoczek M, Bujoczek L (2019) The impact of different management scenarios on the availability of potential forest habitats for wildlife on a landscape level: the case of the black stork Ciconia nigra (Linnaeus, 1758). Forests 10(5):362. https://doi.org/10.3390/f10050362

Basile M, Balestrieri R, de Groot M, Flajšman K, Posillico M (2016) Conservation of birds as a function of forestry. Ital J Agron 11:42-48

Bijak S, Sarzyński J (2015) Accuracy of smartphone applications in the field measurements of tree height. Folia For Pol, Ser A 57(4):240-244. https://doi. org/10.1515/ffp-2015-0025

Brzeziecki B, Drozdowski S, Bielak K, Buraczyk W, Gawron L (2013) Promoting diverse forest stand structure under lowland conditions. Sylwan 157(8):597-606

Chodkiewicz T, Chylarecki P, Sikora A, Wardecki Ł, Bobrek R, Neubauer G, Marchowski D, Dmoch A, Kuczyński L (2019) Raport z wdrażania art. 12 Dyrektywy Ptasiej w Polsce w latach 2013-2018: stan, zmiany, zagrożenia. Biuletyn Monitoringu Przyrody, Bogucki Wydawnictwo Naukowe, Poznań

Cramp S, Simmons KLE (1980) Handbook of the birds of Europe, the Middle East and North Africa. The birds of the Western Palearctic V. 1. Oxford University Press, Oxford

Drobelis E (1993) On the biology and protection of the black stork (Ciconia nigra L.) in Lithuania. Acta Ornithol Lituan 7-8:94-99

Hakkarainen H, Mykrä S, Kurki S, Tornberg R, Jungell S (2004) Competitive interactions among raptors in boreal forests. Oecologia 141:420-424. https://doi.org/10.1007/s00442-004-1656-6

Janssen G, Hormann M, Rohde C (2004) Der Schwarzstorch. Die Neue BrehmBücherei. Bd 468. Westarp Wissenschaften, Hohenwarsleben

Jokimäki J, Solonen T (2011) Habitat associations of old forest bird species in managed boreal forest characterized by forest inventory data. Ornis Fenn 88: $57-70$

Lõhmus A (2003) Do Ural owls (Strix uralensis) suffer from the lack of nest sites in managed forest? Biol Conserv 110:1-9

Lõhmus A, Sellis U (2003) Nest trees - a limiting factor for the black stork (Ciconia nigra) population in Estonia. Aves 40(1):84-91

Lõhmus A, Sellis U, Rosenvald R (2005) Have recent changes in forest structure reduced the Estonian black stork Ciconia nigra population? Biodivers Conserv 14:1421-4132. https://doi.org/10.1007/s10531-004-9667-5

Lontkowski J, Stawarczyk T (2003) Rozwój populacji, wybiórczość siedliskowa i efekty rozrodu bielika Haliaaetus albicilla na Śląsku w latach 1993-2002. Not Orn 44(4):237-248

Mikusiński G, Roberge JM, Fuller RJ (2018) Ecology and conservation of forest bird. Cambridge University Press, Cambridge

Olszewski M, Różycki A, Matusiak J (2017) Wybiórczość środowiskowa miejsc lęgowych oraz typy umiejscowienia gniazd bociana czarnego Ciconia nigra w Kampinoskim Parku Narodowym. Studia i Materiały CEPL 19(2):169-185

Penteriani V (2002) Goshawk nesting habitat in Europe and North America: a review. Ornis Fenn 79:149-163

Poirazidis K, Bontzorlos V (2017) Population trends and multi-scale breeding habitat analysis for the black stork (Ciconia nigra) in Dadia-Lefkimi-Soufl National Park, north eastern Greece. Ann Res Rev Biol 19(4):1-12. https://doi.org/10.9734/ARRB/2017/37663

Pommerening A, Murphy ST (2004) A review of the history, definitions and methods of continuous cover forestry with special attention to afforestation and restocking. Forestry 77(1):37-44

Przybyliński T (2017) Stan populacji lęgowej bielika Haliaeetus albicilla na Ziemi Łódzkiej w drugiej dekadzie XXI wieku. Studia i Materiały CEPL 19(4):42-53

Pugacewicz E (2015) Przebieg regresu białowieskiej populacji bociana czarnego Ciconia nigra w latach 1985-2014. Dubelt 6-7:67-92

R Core Team (2019) R: a language and environment for statistical computing. R Foundation for Statistical Computing, Vienna, Austria. https://www.R-project. org/. Accessed 15 June 2020

Rosenvald R, Lõhmus A (2003) Nesting of the black stork (Ciconia nigra) and white-tailed eagle (Haliaeetus albicilla) in relation to forest management. Forest Ecol Manag 185:217-223

Rosenvald R, Lõhmus A, Kraut A, Remm L (2011) Bird communities in hemiboreal old-growth forests: the roles of food supply, stand structure, and site type. Forest Ecol Manag 262(8):1541-1550

Skuja S, Budrys RR (1999) Nesting sites of black stork, lesser spotted eagle and common buzzard and their nest exchange in the forest of north, north-east and Central Lithuania. Balt For 5(2):67-74
Skuja S, Mozgeris G, Treinys R (2019) May sympatric lesser spotted eagles and black stork compete for nesting sites in spatially varying environments? Balt For 25(1):63-68

Silvicultural Guide (2012) State Forests Information Centre, Warsaw

Stój M (1996) Ptaki drapieżne i bocian czarny Ciconia nigra w Beskidzie Sądeckim. Chrońmy Przyr Ojcz 52(4):38-44

Treinys R, Dementavičius D, Mozgeris G, Skuja S, Rumbutis S, Stončius D (2011) Coexistence of protected avian predators: does a recovering population of white-tailed eagle threaten to exclude other avian predators? Eur J Wildl Res 57:1165-1174

Treinys R, Skuja S, Augutis D, Stončius D (2009b) Nest-site use by black stork and lesser spotted eagle in relation to fragmented forest cover: case study from Lithuania. Ekologija 55(3-4):182-188

Treinys R, Stončius D, Augutis D, Skuja S (2009a) Breeding habitat of the black stork Ciconia nigra in Lithuania: implications for conservation planning. Balt For 15(1):33-40

Vlachos CG, Bakaloudis DE, Alexandrou OG, Bontzorlos V, Papakosta MA (2008) Factors affecting the nest site selection of the black stork, Ciconia nigra in the DadiaLefkimi-Soufli National Park, North Eastern Greece. Folia Zool 57(3):251-257

Walankiewicz W, Czeszczewik D, Stański T, Sahel M, Ruczyński I (2014) Tree cavity resources in spruce-pine managed and protected stands of the Białowieża Forest, Poland. Nat Area J 34(4):423-428. https://doi.org/10.3375/043.034,0404

Zawadzka D, Drozdowski S, Zawadzki G, Zawadzki J (2016) The availability of cavity trees along an age gradient in fresh pine forest. Silv Fenn 50(3):13. https://doi.org/10.14214/sf.1441

Zawadzka D, Mizera T, Cenian Z (2009) Dynamika liczebności bielika Haliaeetus albicilla w Polsce. Studia i Materiały CEPL 11(3):22-31

Zawadzka D, Olech B, Zawadzki J (1990) Zagęszczenie, rozród i pokarm bociana czarnego (Ciconia nigra) w Kampinoskim Parku Narodowym w latach 19791987. Not Orn 31(1-4):5-20

Zawadzka D, Zawadzki G, Zawadzki J, Sołtys A (2017) Dynamika populacji i parametry rozrodu bielika w Puszczy Augustowskiej. Studia i Materiały CEPL 19(4):68-80

Zawadzka D, Zawadzki J, Sudnik W (2006) Rozwój populacji, wymagania środowiskowe i ekologia żerowania bielika Haliaeetus albicilla w Puszczy Augustowskiej. Not Orn 47(4):217-229

Zawadzki G, Zawadzka D (2017) Wybór drzew gniazdowych myszołowa, jastrzębia i kruka w Puszczy Augustowskiej. Sylwan 161(8):669-676

Zbyryt A (2013) Bocian czarny Ciconia nigra. In: Zawadzka D, Ciach M, Figarski T, Kajtoch $Ł$, Rejt $Ł$ (eds) Materiały do wyznaczania i określania stanu zachowania siedlisk ptasich w obszarach specjalnej ochrony ptaków Natura 2000. GDOŚ, Warszawa

Zieliński P (2006) The role of forest reserves in the protection of the black stork Ciconia nigra in Central Poland. Biota 7(1-2):119-123

Zieliński P, Janic B, Kamiński M, Stopczyński M, Marszał L, Szpetmańska H, Bańbura J (2017) Wzrost liczebności i zagęszczenie bociana czarnego Ciconia nigra w Polsce środkowej. Chrońmy Przyr Ojcz 73(2):101-109

Zieliński P, Stopczyński M, Janic B, Gapys A, Bańbura J (2011) Czy ochrona strefowa miejsc gniazdowych bociana czarnego jest wystarczająca? Studia i Materiały CEPL 13(2):49-56

Zuberogoitia I, Martinez JE (2011) Ecology and conservation of European forestdwelling raptors. Departamento de Agricultura de la Diputación Foral de Bizkaia, Bilbao

\section{Submit your manuscript to a SpringerOpen ${ }^{\circ}$ journal and benefit from:}

- Convenient online submission

- Rigorous peer review

- Open access: articles freely available online

- High visibility within the field

- Retaining the copyright to your article

Submit your next manuscript at $>$ springeropen.com 